\title{
Elemen Pengambilan Keputusan yang Tepat dan Efektif Dalam Asuhan Keperawatan
}

Fitri Rahman Batubara

\section{Fitri.batubara.fr@gmail.com}

\begin{abstract}
Abstrak
Pengambilan keputusan merupakan salah satu bentuk perbuatan berfikir dan hasil dari suatu perbuatan itu disebut keputusan. Pengambilan keputusan dalam psikologi kognitif difokuskan pada bagaimana seorang mengambil keputusan. Dalam kajiannya berbeda dengan pemecahan masalah yang mana ditandai dengan situasi dimana sebuah tujuan ditetapkan dengan jelas dan dimana pencapaian sebuah sasaran diuraikan menjadi sub tujuan, yang pada saatnya membantu menjelaskan tindakan yang harus dan kapan diambil. Pengambilan keputusan juga berbeda dengan penalaran yang mana ditandai dengan sebuah proses oleh perpindahan seseorang dari apa yang telah mereka ketahui terhadap pengetahuan lebih lanjut. Perawat perlu menggunakan langkah-langkah dalam melakukan proses perawatan. Langkah-langkah proses perawatan tersebut meliputi pengumpulan data, pengidentifikasian masalah atau kebutuhan, penetapan tujuan, pengidentifikasian hasil dan pemilihan intervensi keperawatan untuk mencapai hasil serta tujuan yang diharapkan, dengan menentukan keberhasilan penyelesaian masalah.
\end{abstract}

Kata Kunci : Elemen Pengambilan Keputusan, Asuhan Keperawatan 
1. Latar Belakang

Keputusan merupakan hasil pemecahan dalam seuatu masalah yang harus dihadapi dengan tegas dalam kamus besar ilmu pengetahuan pengambilan keputusan (Decision Making)

didefinisikan sebagai pemilihan keputusan atau kebijakan yang didasarkan atas kriteria tertentu. Proses ini meliputi dua alternatif tidak akan ada satu keputusan yang akan diambil.

Menurut J.Reeson pengambilan keputusan dapat dianggap sebagai suatu hasil atau keluaran dari proses mental atau kognitif yang membawa pada pemilihan suatu jalur tindakan diantara beberapa alternatif yang tersedia. Setiap proses pengambilan keputusan selalu menghasilkan satu pilihan final.

pengambilan keputusan adalah proses pemikiran yang berupa pilihan satu antara beberapa alternatif yang digunakan sebagai penentu dari sejumlah pilihan, serta dicapai setelah dilakukan pertimbangan yang dipengaruhi oleh kognitif, analisi, dan pengalama untuk memecahakan masalah yang dihadapi. Pengambilan keputusan sering terjadi baik disadari maupun tidak disadari, berdasarkan pengumpulan fakta dan data, sebagai penentu keputusan yang dibuat agar dapat mengambil tindakan yang tepat.

Hubungan perawat klien adalah dasar dari praktik keperawatan yang berfokus pada pasien (patient centered care). Keterlibatan pasien merupakan inti dari proses keperawatan, sehingga partisipasi pasien dalam proses keperawatan menjadi penting dalam penentuan kualitas dan efektifitas dalam pelayanan asuhan keperawatan. Membina hubungan ini didasarkan pada hubungan yang percaya, menghormati dan hubungan profesianal dengan mengedepankan nilai etik dan disiplin profesi. Selama praktek, profesional keperawatan menghadapi sejumlah situasi yang berbeda melibatkan klien dan pemenuhannya yang berbeda pula. Proses pengambilan keputusan klinis merupakan komponen penting dalam proses keperawatan, sehingga dibutuhkan kemampuan perawatan karena Keterbatasan pengetahuan dan kemampuan yang dimiliki perawat dapat 
menghambat perawat dalam mengambil keputusan mengenai perawatan yang akan diberikan kepada klien yang akan berakibat fatal terhadap klien. Penilaian dan keputusan klinis sangat dibutuhkan untuk mendapatkan kualitas pelayanan yang optimal.

Pemberian asuhan keperawatan harus berdasarkan nilai-nilai dan etika yang dianut oleh klien dan nilai-nilai profesional asuhan keperawatan. Mengkombinasikan nilai profesional, etik dan nilai yang di anut klien akan meningkatkan pelayanan, identifikasi kebutuhan dan masalah keperawatan lebih sistematis sehingga meningkatkan pemahaman klien dalam pengambilan keputusan asuhannya.

\section{Metode}

Metode yang digunakan adalah literature review atau studi pustaka . Literature review yang dilakukan pengkajian serta menganalisis jurnal, text book, dan ebook yang relevan dan berfokus pada proses keperawatan sebagai system pelayanan kesehatan. Adapun sumber yang digunakan yaitu diterbitkan pada 10 tahun terakhir.
Melalui metode ini saya memahami dan mengidentikasi perencanaan keperawatan, bagaimana membuat prioritas masalah, membuat tujuan dan kriteria hasil, memutuskan perencanan keperawatan yang akan diimplementasikan. Metode ini juga berusaha menjelaskan, mengumpulkan, dan menginterpretasikan data yang dilanjutkan dengan faktor-faktor yang berhubungan dengan situasi dan kondisi yang terjadi.

\section{Hasil}

Hasil penelusuran literatur menunjukan bahwa proses pengambilan keputusan merupakan sebuah refleksi dari perawat ataupun klien, pengambilan keputusan klinis keperawatan harus ada interaksi antara perawat-klien, pengambilan keputusan klinis keperawatan dapat dilakukan dalam setiap proses keperawatan, tugas perawat pada saat proses pengambilan keputusan ini adalah sebagai fasilitator untuk memberikan fasilitas dan dukungan pada klien, pengambilan keputusan klinis dengan melibatkan klien akan meningkatkan tingkat kemandirian bagi klien, 
pengambilan keputusan klinis diperlukan kemampuan berfikir kritis bagi perawat. Yang terjadi di Indonesia pengambilan keputusan belum sepenuhnya dilakukan bersama antara perawat-klien. Perawat masih berperan sebagai pengambil keputusan tunggal. Sehingga dibutuhkan pemahaman lebih lanjut terkait dengan pengambilan keputusan klinis keperawatan dengan harapan peran perawat akan lebih terlihat nyata sebagai pemberi asuhan yang akan meningkatkan kepercayaan masyarakat terhadap profesi keperawatan.

Penyelesaian masalah dan pengambilan keputusan bukan merupakan bentuk sinonim. Pemecahan masalah dan proses pengambilan keputusan membutuhkan pemikiran kritis dan analisis yang dapat ditingkatkan dalam praktek. Pengambilan keputusan merupakan upaya pencapaian tujuan dengan menggunakan proses yang sistematis dalam memilih alternatif. Tidak semua pengambilan keputusan dimulai dengan situasi masalah.
Pemecahan

masalah termasuk dalam langkah proses pengambilan keputusan, yang difokuskan untuk mencoba memecahkan masalah secepatnya. Masalah dapat digambarkan sebagai kesenjangan diantara "apa yang ada dan apa yang seharusnya ada". Pemecahan masalah dan pengambilan keputusan yang efektif diprediksi bahwa individu harus memiliki kemampuan berfikir kritis dan mengembangkan dirinya dengan adanya bimbingan dan role model di lingkungan kerjanya.

Pengambilan keputusan dalam penyelesaian masalah adalah kemampuan mendasar bagi praktisi kesehatan, khususnya dalam asuhan keperawatan dan kebidanan. Tidak hanya berpengaruh pada proses pengelolaan asuhan keperawatan dan kebidanan, tetapi penting untuk meningkatkan kemampuan merencanakan perubahan. Perawat dan bidan pada semua tingkatan posisi klinis harus memiliki kemampuan menyelesaikan masalah dan mengambil keputusan yang efektif.

\section{Pembahasan}


Pengambilan keputusan adalah suatu proses penilaian dan pemilihan dari berbagai alternatif sesuai dengan kepentingan-kepentingan tertentu dengan menetapkan suatu pilihan yang dianggap paling menguntungkan (Machfoedz, 2005). Menurut Kotler \& Keller (2007) keputusan pembelian merupakan sebuah tahapan konsumen secara aktual mengambil keputusan pembelian. Konsumen mungkin juga membentuk maksud untuk membeli merek yang disukai. Proses keputusan pembelian itu sendiri tergantung dengan persepsi masing-masing konsumen. Keputusan membeli terjadi melalui proses perilaku yang terdiri dari pengenalan masalah, mencari informasi, evaluasi terhadap alternative dan hasil atau perilaku setelah membeli.

Pasien sebagai konsumen memiliki hak-hak yang sudah diatur dalam UU Keperawatan pasal 38 yakni pasien berhak mendapatkan informasi secara benar, jelas dan jujur tentang tindakan keperawatan yang akan dilakukan; pasien berhak meminta pendapat perawat lain dan/atau tenaga kesehatan lainnya; pasien berhak mendapatkan pelayanan keperawatan sesuai dengan kode etik, standar pelayanan keperawatan, standar profesi, standar prosedur operasional dan ketentuan peraturan perundangundangan; pasien berhak memberi persetujuan atau penolakan tindakan keperawatan yang akan diterimanya; dan pasien berhak memperoleh keterjagaan kerahasiaan kondisi kesehatannya.

Proses pengambilan keputusan dalam praktik klinik keperawatan dipahami sebagai serangkaian keputusan yang dibuat oleh perawat dalam interaksinya dengan pasien mengenai jenis pengamatan yang akan dilakukan dalam situasi yang di alami klien (pengkajian keperawatan), perumusan diagnosa keperawatan, rencana tindakan keperawatan yang harus diambil, tindakan keperawatan yang akan diambil serta evaluasi. Perlu difahami bahwa istilah keputusan klinis merupakan pilihan dianatara alternatif yang ada sebagai upaya pemecahan masalah.

Beberapa konsep yang digunakan untuk menggambarkan berpikir kritis dalam keperawatan adalah penalaran klinis, perumusan diagnostik, pengambilan keputusan, penilaian, dan pemecahan maslah. Menurut penelitian yang dilakukan oleh 
Panggabean, 2019 kemampuan

berfikir kritis perawat dalam pengambilan keputusan klinis berhubungan erat dengan kemampuan berfikir kritis perawat. Berpikir kritis digambarkan sebagai "sebuah proses, tujuan untuk membuat keputusan yang masuk akal tentang apa yang harus percaya dan apa yang harus dilakukan". Pengambilan keputusan klinis adalah sebuah proses yang melibatkan kedua penalaran diagnostik dan penilaian klinis. Tindakan dalam ini tindakan diarahkan sebagai proses refleksi dari perawat maupun pasien.

Pengambilan keputusan sangat penting keberadaannya dalam asuhan maupun dalam manajemen keperawatan. Pengambilan keputusan merupakan suatu proses yang mencakup semua penilaian kegiatan yang diperlukan guna membuktikan dan meperlihatkan pilihan terbaik dalam menyelesaiakan suatu masalah tertentu. setiap keputusan adalah akibat dari sebuah proses dinamis yang dipengaruhi oleh banyak kekuatan, pengambilan keputusan bukan merupakan prosedur yang tetap akan tetapi sebuah proses yang beruntun. pengambilan keputusan adalah proses yang melibatkan pendekatan sistemik yang harus diadaptasikan dengan lingkungan.

Bagaimanan perawat dalam mengambil keputusan klinis? Pengambilan keputusan keperawatan dilakukan pada semua tahap proses keperawatan. Sehingga seorang perawat harus mampu berpikir ktitis, berkomunikasi dengan baik sebagai suatu elemen penting dalam pengaambilan keputusan klinis, sehingga terjadi pembelajaran berkelanjutan bagi pasien sehingga meningkatkan tingkat kemandirian pasien. pengambilan keputusan klinis merupakan bagian dari kobarorasi klien dan pemberi pelayanan kesehatan dalam hal ini adalah

perawat. Sehingga seorang perawat dituntut mampu untuk melakukan pengambilan keputusan dengan melibatkan klien, perawat bukan pengambil keputusan tunggal akan tetapi sebagai fasilitator bagi klien.

Ketepatan pengambilan keputusan akan di pengaruhi oleh kompentisi perawat, kemampuan berkomunikasi, lingkungan serta budaya. Penting bagi perawat 
untuk selalu meningkatkan kapasitas dirinya dalam pemberian asuhan keperawatan hal ini akan meningkatkan kepercayaan masyarakat terhadap perawat yang selanjutnya akan meningkatkan profesionalisme perawat. Hal ini bisa digunakan sebagai acuan dalam melakukan hubungan interdisiplin.

Pengambilan keputusan yang tepat akan meningkatkan kemandian klien dalam asuhannya serta membantu klien untu menentukan pilihan bantuan yang tepat sesuai dengan kondisinya. Klien yang mandiri akan menurunkan beban kerja perawat sehingga pelayanan keperawatan akan lebih efektif dan efisien dalam penggunaan sumber daya.

Ada dua faktor yanh berpengaruh dalam pengambilan keputusan, antara lain:

\section{Faktor Internal}

Faktor internal dari diri manajer sangat mempengaruhi proses pengambilan keputusan. Faktor internal tersebut meliputi: keadaan emosional dan fisik, personal karakteristik, kultural, sosial, latar belakang filosofi, pengalaman masa lalu, minat, pengetahuan dan sikap pengambilan keputusan yang dimiliki.

\section{Faktor Eksternal}

Faktor eksternal termasuk kondisi dan lingkungan waktu. Suatu nilai yang berpengaruh pada semua aspek dalam pengambilan keputusan adalah pernyataan masalah, bagaimana evaluasi itu dapat dilaksanakan. Nilai ditentukan oleh salah satu kultural, sosial, latar belakang, filosofi, sosial dan kultural.

Sistem pelayanan kesehatan seharusnya dapat menyediakan informasi yang terbuka kepada pasien dan keluarganya. Dengan demikian, mereka akan menentukan pilihan terhadap lembaga pelayanan kesehatan atau rumah sakit yang akan mereka kunjungi, lembaga asuransi kesehatan untuk menjamin kesehatannya dan jenis terapi yang akan dijalani.

Cara terbaik untuk memberikan saran adalah dengan mengajukan beberapa pilihan serta hal-hal yang bisa dilakukan. Diskusikan bersama tentang efek posistif dan negatif dari setiap pilihan yang disarankan. Saran dapat berasal dari teman, keluarga dan orang-orang terdekat. Setelah mendapatkan saran, akan lebih baik jika mempertimbangkan kembali saran yang telah diterimanya. Sehingga dalam membuat keputusan akan sesuai dengan pilihannya. 
Pengambilan keputusan sangat penting dalam menentukan asuhan keperawatan kepada pasien. Perawat harus mempertimbangkan banyak faktor yang berpotensi mempengaruhi proses pengambilan keputusan dalam memenuhi kebutuhan pasien. Perawat harus mempunyai kemampuan yang baik untuk pasien maupun dirinya didalam menghadapi masalah yang menyangkut etika. Seseorang harus berpikir secara rasional, bukan emosional dalam membuat keputusan etis. Keputusan tersebut membutuhkan keterampilan berpikir secara sadar yang diperlukan untuk menyelamatkan keputusan pasien dan memberikan asuhan. Kemampuan membuat keputusan masalah etis menjadi salah satu persyaratan bagi perawat untuk menjalankan praktik keperawatan professional.

Pengambilan keputusan yang tepat menggunakan suatu pendekatan yang sistematis terhadap hakekat suatu masalah dengan pengumpulan fakta-fakta dan data. Dalam menentukan alternatif yang matang untuk mengambil suatu tindakan yang tepat didasarkan pada kriteria tertentu atas dua atau lebih alternatif yang sesuai. Pengambilan keputusan dalam penyelesaian masalah membutuhkan kemampuan yang mendasar bagi praktisi kesehatan, khususnya dalam asuhan keperawatan. Pengambilan keputusan tidak hanya berpengaruh pada proses pengelolaan asuhan keperawatan, tetapi penting untuk meningkatkan kemampuan merencanakan perubahan. Perawat pada semua tingkatan posisi klinis harus memiliki kemampuan menyelesaikan masalah dan mengambil keputusan yang efektif, baik sebagai pelaksana/staf maupun sebagai pemimpin.

Salah satu strategi dalam transformasi organisasi dalam pelayanan kesehatan saat ini adalah empowerment terhadap staf. Pembagian kekuasaan (power) dengan staf dijadikan sebagai suatu strategi dalam transformasi organisasi pelayanan kesehatann. Manajer memberdayakan pekerjaan karyawan, mempelajari cara mengambil tanggung jawab untuk pekerjaan dan membuat keputusan yang tepat. Empowerment merupakan pemberdayaan dalam lingkungan kerja terhadap anggota organisasi. Lingkungan kerja yang menyediakan akses informasi, sumber, dukungan, dan kesempatan untuk belajar serta berkembang merupakan suatu pemberdayaan (empowerment).

Teori empowerment dipakai dalam upaya merumuskan strategi manajemen untuk peningkatan lingkungan kerja yang positif di bidang keperawatan. Teori tersebut sudah banyak dipakai dalam penelitian di bidang perilaku organisasi karena berguna untuk membentuk berbagai 
intervensi organisasi untuk meningkatkan kondisi kerja dalam lingkungan keperawatan. Perawat dengan akses lingkungan empowerment memberikan dampak positif pada organisasi. Perawat yang mendapatkan lingkungan dengan pemberdayaan (empowerment) memberikan dampak pada penyelenggaraan pelayanan kepada pasien, ketegangan kerja, kepuasan kerja dan retensi perawat ditempat kerja. Praktik dari manajemen ini tidak hanya meningkatkan kontribusi atau produktifitas perawat dengan efektif tetapi juga memungkinkan perawat untuk melatih otonomi, merasakan, dan mengerti akan nilai- nilai terhadap kerja dan kepuasan.

Strategi empowerment memicu partisipasi aktif perawat dalam membuat keputusan. Implementasi empowerment pada perawat membawa peningkatan otonomi profesional serta partisipasi aktif dalam membuat keputusan pada isu-isu praktik keperawatan dan lingkungan kerja. Mempertimbangkan pentingnya pengambilan keputusan perawat dalam menghadapi masalah dan manfaat dari empowerment. Tujuan dari disusunnya studi ini adalah untuk menganalisis pengaruh empowerment terhadap pengambilan keputusan perawat.
Seorang

manajer

keperawatan/kebidanan harus mempunyai keberanian untuk mengambil keputusan dan memikul tanggung jawab atas akibat dari resiko yang timbul sebagai konsekuensi dari keputusan yang telah diambilnya. Pada hakekatnya, pengambilan keputusan adalah suatu pendekatan yang sistematis terhadap hakekat suatu masalah yang difokuskan untuk memecahkan masalah secepatnya dimana individu harus memiliki kemampuan berfikir kritis dengan menggunakan pendidikan dan pengalaman yang berharga yang cukup efektif dalam pemecahan masalah.

\section{Penutup}




\section{Referensi}

Bandiyah, Siti. 2017. Ketrampilan Dasar Keperawatan. Yogyakarta: Nuha Medika

Candra D. R., Sri $\quad$ M. 2020. PENGAMBILAN KEPUTUSAN KLINIS KEPERAWATAN. Jurnal Ilmiah Kesehatan, 1(1).

Fergie M. M., Jootje M., Joy A. 2015. ANALISIS FAKTOR-FAKTOR YANG BERHUBUNGAN DENGAN KINERJA PERAWAT DALAM MENERAPKAN ASUHAN KEPERAWATAN DI RUMAH SAKIT UMUM BETHESDA GMIM TOMOHON. Jurnal e-Biomedik, 3(3).

Kiki D., Ria A., Tini S. 2018. Pengaruh Berfikir Kritis Terhadap Kemampuan Perawat Pelaksana Dalam Melakukan Asuhan Keperawatan Di Rumah Sakit Hermina Bekasi Tahun 2016. Jurnal Kesehatan Holistik, 12(1).

Nursalam. 2014. Manajemen Keperawatan Aplikasi dalam Praktik Keperawatan Profesional. Jakarta: Salemba Medika.

Nursalam. 2015. Metodologi Penelitian Ilmu Keperawatan (4th ed). Jakarta: Salemba Medika.
Pangaribuan, Resmi. (2016). Persepsi Perawat Terhadap Prinsip-prinsip Etik dalam Pelaksanaan Tindakan Keperawatan di ICU Rumah Sakit TK. II Putri Hijau. Jurnal Riset Hesti Medan, 1(1), 37-44.

Rahayu, CD., Mulyani, S. 2020. Pengambilan Keputusan Klinis Perawat. Jurnal Ilmiah

Kesehatan. 1-11

Simamora, R. H. 2005. Hubungan Persepsi Perawat Pelaksana Terhadap Penerapan Fungsi Pengorganisasian Yang Dilakukan Oleh Kepala Ruangan Dengan Kinerjanya Diruang Rawat Inap RSUD Koja Jakarta Utara (Doctoral dissertation, Tesis FIK UI, Tidak dipublikasikan).

Simamora, R. H. (2019). Menjadi perawat yang: CIH'HUY. Surakarta: Kekata Publisher.

Sumijatun. 2011. Membudayakan Etika dalam Praktik Keperawatan. Jakarta : Salemba Medika.

Tedjomuljo, Selvyyanny,. Efy Afifah. 2016. Tingkat Pengetahuan Mahasiswa Keperawatan Tentang Kode Etik Profesi dan Caring. Jurnal Keperawatan Indonesia, 19(2), 129-136. 
